\title{
HLA-DRB1 gene polymorphisms in pediatric patients with type 1 autoimmune hepatitis and type 1 autoimmune hepatitis overlap syndrome with autoimmune cholangitis
}

\author{
Monique Ellen Gervásio NUNES ${ }^{1}$, Daniela Valadão ROSA ${ }^{1}$, Eleonora Druve Tavares FAGUNDES ${ }^{2}$, \\ Alexandre Rodrigues FERREIRA ${ }^{2}$, Débora Marques de MIRANDA ${ }^{1}$ and Priscila Menezes FERRI LIU²
}

Received 8/1/2019 Accepted 19/3/2019

\begin{abstract}
Background - Autoimmune hepatitis (AIH) is a rare chronic inflammatory liver disease associated with a loss of immunological tolerance to self-antigens. Susceptibility to AIH is partially determined by the presence of genes related to human leukocyte antigen $(H L A)$, mainly allelic variants of $D R B 1$. Objective - The purpose of this study was to investigate the frequencies of the polymorphisms in $H L A-D R B 1$ gene in children and adolescents with type $1 \mathrm{AIH}$ and type $1 \mathrm{AIH}$ overlap syndrome with autoimmune cholangitis (overlap syndrome, OS) in comparison to healthy sex and age-matched individuals (control group). Methods - This is a cross-sectional study of 25 pediatric patients diagnosed with type 1 AIH and 18 with OS. Fifty-seven healthy individuals were included as controls. The polymorphisms of the $H L A-D R B 1$ gene were evaluated by PCR and included $H L A-D R B 1 * 03, H L A-D R B 1 * 04, H L A-D R B 1 * 07$, and $H L A-D R B 1 * 13$. Results - Our results showed that the presence of the allele $H L A-D R B 1 * 13$ increased the chance of autoimmune cholangitis $(\mathrm{OR}=3.96$, CI 1.07 to $14.61, P=0.04)$. The HLA-DRB $1 * 04$ and HLA- DRB1*07 have no association with the AIH and autoimmune cholangitis in a young sample. Conclusion - This work demonstrates an association of the main polymorphisms in the $H L A-D R B 1$ gene to AIH with or without cholangitis in a Brazilian sample.
\end{abstract}

HEADINGS - Autoimmune hepatitis. Sclerosing cholangitis. $H L A-D R B 1$ chains. Genetic polimorphism.

\section{INTRODUCTION}

Type 1 autoimmune hepatitis $(\mathrm{AIH})$ is a rare chronic inflammatory liver disease associated with loss of immunological tolerance to self-antigens ${ }^{(1-3)}$. Histologically, AIH is characterized by interface chronic hepatitis in the absence of a known cause ${ }^{(1)}$. AIH is uncommon in children, occurring between 10 and 30 years old ${ }^{(2)}$. Clinically, the disease can vary from asymptomatic liver disease to hepatic failure ${ }^{(2,3)}$. AIH type 1 overlap syndrome with autoimmune cholangitis or overlap syndrome (OS) is more common among children and adolescents, reaching almost $30 \%$ to $50 \%$ of pediatric population ${ }^{(3,4)}$. OS is characterized by AIH with features of primary sclerosing cholangitis ${ }^{(4)}$.

The etiology of AIH is not entirely known. As a complex disorder, many genes may interact with environmental factors resulting in disease $\mathrm{e}^{(5-8)}$. Susceptibility to AIH is partially determined by the presence of genes related to major histocompatibility complex II (MHC II), especially the allelic variants of $D R B 1$ of human leukocyte antigen $(H L A)^{(8-11)}$. Among white North American and Northern European individuals, AIH has been associated with $H L A-D R B 1^{*} 03$ and $H L A-D R B 1^{*} 04^{(6,12-16)}$. In children, $H L A$ $D R B 1^{*} 13$ is related to susceptibility to $\mathrm{AIH}$, to the prognosis and to the response to treatment ${ }^{(17)}$. Czaja et al. 2002 concluded that patients with $H L A-D R B 1^{*} 03$ were younger at disease onset than patients with $H L A-D R B 1^{*} 04$, and they also had worse response to treatment with corticosteroids ${ }^{(17)}$. Patients expressing $H L A$ $D R B 1 * 04$ were more often women, with a greater chance of exhibiting other autoimmune diseases and with good response to corticosteroids $^{(17,18)}$.

Few studies have evaluated the frequencies of $H L A-D R B 1$ gene polymorphisms in pediatric patients with AIH and their relationship with clinical features. In this regard, the purpose of this study was to describe frequencies of the polymorphisms in HLA gene and to investigate the association of these polymorphisms with AIH and with OS. All findings were compared to healthy age and sex-matched controls.

\section{METHODS}

\section{Patients and controls}

This cross-sectional study included 43 pediatric patients, being 25 with type $1 \mathrm{AIH}$ and 18 with OS (type 1 AIH overlap syndrome with autoimmune cholangitis). Patients were followed at Hepatology Reference Center of our institution (Hospital das Clínicas, Universidade Federal de Minas Gerais - UFMG, Brazil) from January 1986 to January 2014. Diagnosis of AIH was estab-

Declared conflict of interest of all authors: none

Disclosure of funding: no funding received

${ }^{1}$ Universidade Federal de Minas Gerais, Faculdade de Medicina, Laboratório de Medicina Molecular, Belo Horizonte, MG, Brasil. ${ }^{2}$ Universidade Federal de Minas Gerais, Hospital das Clínicas, Serviço de Gastroenterologia Pediátrica, Belo Horizonte, MG, Brasil.

Corresponding author: Débora Marques de Miranda. E-mail: debora.m.miranda@gmail.com, deborammiranda@ufmg.br 
lished according to the criteria of the International Group for the Study of AIH, published in 1993 and revised in 1999 and $2008^{(19,20)}$. Diagnosis of OS was based on the presence of abnormalities in biliary tract, including stenosis and/or dilatation of intra- and/or extra-hepatic ducts on magnetic resonance imaging (MRI) of the biliary tract. MRI was performed in patients with persistent elevation of gamma glutamyl transferase (GGT) and/or poor response to immunosuppressive treatment. Three pediatric hepatologists and two radiologists independently reviewed the biliary tract images. Liver histology was also assessed.

Control group included 57 healthy individuals; age and sex matched with patients and the samples were collected at National Institute of Molecular Medicine Center (UFMG, Brazil). Healthy status was determined through the subjects' medical history and either a parental report or self-report to rule out the presence of personal and family history of autoimmune diseases.

The study was approved by the Ethics Committee of our institution under the protocol ETIC\#0419.0.203.000-10. Research protocol did not interfere with treatment. The consent form was read and signed by parents, researchers and patients when appropriate.

\section{Clinical and laboratory monitoring}

Follow-up visits consisted of clinical and laboratory evaluations at each 1 to 6 months, according to disease onset, protocol for diagnosis and therapeutic approach. Other etiologies of liver diseases were investigated and properly excluded, including infectious hepatitis, Wilson's disease and deficiency of alpha-1-antitrypsin. All patients performed liver biopsy for disease staging. Diagnosis of OS was confirmed with the MRI of hepatic biliary tract and histological findings. Clinical features at disease onset were described for patients with AIH and with OS.

\section{DNA Extraction and PCR-SSP}

After informed consent, patients and controls were submitted to an intravenous puncture to collect $10 \mathrm{~mL}$ of peripheral blood samples. Genomic DNA was extracted using a saline method from the total blood ${ }^{(21)}$. The DNA concentration was adjusted to $50 \mathrm{ng} /$ uL subsequently. HLA-DRBI locus was performed using polymerase chain reaction and sequence-specific primers (PCR-SSP), as described elsewhere ${ }^{(22)}$. The polymorphisms evaluated were $H L A$ $D R B 1^{*} 03, H L A-D R B 1 * 04, H L A-D R B 1 * 07$, and $H L A-D R B 1^{*} 13$. The alleles sequence specific primers were designed based on previously reported reference ${ }^{(23)}$ and confirmed from GenBank database. The primers were synthesized by Thermo Fisher Scientific, Invitrogen and Integrated DNA Technologies (IDT).

Every PCR reaction tube contains $50 \mathrm{ng}$ genomic DNA to be tested, $0.5 \mathrm{U}$ Taq polymerase, $0.5 \mathrm{mmol}$ of dNTP, $1.5 \mathrm{mmol}$ of $\mathrm{MgCl}_{2}, 0.2 \mathrm{mmol}$ SSP of each HLA-DRB1 alleles. Conditions for PCR: denaturation at $95^{\circ} \mathrm{C}$ for $1 \mathrm{~min}$; annealing temperature was specific to each primer for $30 \mathrm{~s}$; elongation at $72^{\circ} \mathrm{C}$ for $1 \mathrm{~min}, 35$ cycles. PCR products were analyzed by electrophoresis $(100 \mathrm{~V}, 400$ $\mathrm{mA}, 60 \mathrm{~min}$ ) of $1 \%$ ethidium bromide agarose gel. Two polymorphisms (HLA DRB1* 04 and HLA- DRB1*07) were visualized in silver-stained $6.5 \%$ polyacrylamide gel.

\section{Statistical analyses}

Statistical analysis was performed using the software SPSS (IBM, Chicago, IL). Variables were checked for Gaussian distribution and were expressed as means and standard deviation or medians and interquartile range, when appropriated. Categorical variables and percentages were compared with chi-square and Fisher's exact test. Unpaired student t-test was used for comparisons of means between two groups, while Mann Whitney test compared medians of two groups. The chance to have AIH or OS based on the presence of polymorphisms was expressed as odds ratio (OR) and confidence intervals (CI). For all comparisons, the level of significance was set at $P<0.05$.

\section{RESULTS}

\section{Clinical and demographic characteristics of patients and controls}

A total of 100 individuals were investigated, being 43 patients with AIH or OS and 57 healthy controls. Patients were divided in two subgroups: AIH $(n=25)$ and OS $(n=18)$. Controls were age $(15.86 \pm 6.34$ years in patients versus $13.92 \pm 4.55$ years in controls, $P>0.05)$ and sex-matched with patients $(65 \%$ of females among patients and the same percentage among controls, $P>0.05$ ) at the time of blood collection.

In regard to disease onset, no significant differences were detected when patients with AIH were compared to patients with OS (TABLE 1).

TABLE 1. Comparison of the main clinical features of patients with AIH and with OS.

\begin{tabular}{lccc}
\hline & $\begin{array}{c}\text { Autoimmune } \\
\text { hepatitis } \\
(\mathrm{n}=25)\end{array}$ & $\begin{array}{c}\text { Overlap } \\
\text { syndrome (n=18) }\end{array}$ & $\boldsymbol{P}$ value \\
\hline $\begin{array}{l}\text { Mean of age at } \\
\text { disease onset (years) }\end{array}$ & $9.1( \pm 3.1)$ & $8.52( \pm 3.3)$ & 0.61 \\
Gender (females n) & $19(76 \%)$ & $10(55.5 \%)$ & 0.15
\end{tabular}

Disease presentation, number of patients (percentage)

$\begin{array}{lccc}\text { Liver failure } & 2(8 \%) & 3(16.7 \%) & 0.38 \\ \text { Acute onset } & 8(32 \%) & 2(11.1 \%) & 0.10 \\ \begin{array}{l}\text { Chronic liver } \\ \text { disease }\end{array} & 12(48 \%) & 9(50 \%) & 0.89 \\ \text { Asymptomatic } & 3(12 \%) & 4(22.2 \%) & 0.37\end{array}$

\section{Laboratory data from patients with type $1 \mathrm{AlH}$ and with OS (type 1 AlH overlap syndrome with autoimmune cholangitis)}

Comparison of the laboratory features between patients group are presented in TABLE 2 and there was no statically difference in the parameters evaluated (TABLE 2). We have autoantibodies positivity and laboratory measures data from 24 patients with type $1 \mathrm{AIH}$ (one patient evolved to death) and 18 patients with OS.

\section{Frequencies of polymorphisms}

TABLES 3 and 4 presents the frequencies of polymorphisms of HLA-DRB $1 *$ gene in patients with AIH, OS and in control group. The polymorphism of HLA-DRB $1 * 13$ had higher frequency in AIH group than in overlap syndrome or control group. The frequencies of other polymorphisms of HLA-DRB $1 *$ gene $(03,04$ and 07$)$ were similar in patients with $\mathrm{AIH}$, with $\mathrm{OS}$ and in control group. 
TABLE 2. Comparison of the laboratory features between two groups of patients with $\mathrm{AIH}$ and $\mathrm{AIH}$ in association with autoimmune cholangitis (overlap syndrome)

\begin{tabular}{|c|c|c|c|}
\hline & $\begin{array}{c}\text { AIH }(n=24 \\
\text { patients) }\end{array}$ & $\begin{array}{c}\text { AIH associated } \\
\text { with } \\
\text { autoimmune } \\
\text { cholangitis } \\
\text { (n=18 patients) }\end{array}$ & $P$ value* \\
\hline \multicolumn{4}{|c|}{ Autoantibodies positivity } \\
\hline$A S M A$ & $19(79 \%)$ & $15(83 \%)$ & \\
\hline$A N A$ & $16(67 \%)$ & $12(66 \%)$ & \\
\hline ANTILKM1 & $01(4 \%)$ & $0(0 \%)$ & \\
\hline \multicolumn{4}{|c|}{ Laboratory measures (median and Std Dev.) } \\
\hline GGT & $\begin{array}{c}123.2 \\
( \pm 72.84)\end{array}$ & $182.7( \pm 122.00)$ & 0.06 \\
\hline Albumin & $\begin{array}{c}3.52 \\
( \pm 0.62) \mathrm{g} / \mathrm{dL}\end{array}$ & $\begin{array}{c}3.59 \\
( \pm 0.56) \mathrm{g} / \mathrm{dL}\end{array}$ & 0.72 \\
\hline Gammaglobulinemia & $\begin{array}{c}2.70 \\
( \pm 1.07) \mathrm{g} / \mathrm{dL}\end{array}$ & $\begin{array}{c}3.68 \\
( \pm 1.48) \mathrm{g} / \mathrm{dL}\end{array}$ & 0.05 \\
\hline Prothrombin activity & $\begin{array}{c}60.29 \\
( \pm 19.24) \%\end{array}$ & $\begin{array}{c}62.72 \\
( \pm 20.60) \%\end{array}$ & 0.69 \\
\hline
\end{tabular}

AIH: autoimmune hepatitis. $*$ Statistical significance.

TABLE 3. Frequency of polymorphisms of the HLA-DRB1* gene in $\mathrm{AIH}, \mathrm{OS}$ and control groups.

\begin{tabular}{|c|c|c|c|c|}
\hline \multirow{2}{*}{ Groups } & \multicolumn{4}{|c|}{ Polymorphism of $H L A-D R B 1^{*}$} \\
\hline & 0301 & $0401 \%(n)$ & $0701 \%(n)$ & $1301 \%(n)$ \\
\hline $\mathrm{AIH}$ & $12 \%(12)$ & $5 \%(5)$ & $1 \%(1)$ & $19 \%(19)$ \\
\hline Overlap syndrome & $9 \%(9)$ & $1 \%(1)$ & $2 \%(2)$ & $8 \%(8)$ \\
\hline Control & $7 \%(7)$ & $4 \%(4)$ & $11 \%(11)$ & $8 \%(8)$ \\
\hline Total & $28 \%(28)$ & $10 \%(10)$ & $14 \%(14)$ & $35 \%(35)$ \\
\hline
\end{tabular}

AIH: autoimmune hepatitis.

TABLE 4. Numbers and percentages described are related to 100 individuals (43 patients and 57 controls).

\begin{tabular}{lccc}
\hline $\begin{array}{l}\text { Polymorphism of } \\
\text { HLA-DRB1, n }(\%) 100\end{array}$ & $\begin{array}{c}\text { AIH } \\
\text { patients }\end{array}$ & OS patients & Controls \\
\hline 0301 & 12 & 9 & 7 \\
0401 & 5 & 1 & 4 \\
0701 & 1 & 2 & 11 \\
1301 & 19 & 8 & 8 \\
\hline
\end{tabular}

AIH: autoimmune hepatitis. OS: overlap syndrome.

\section{Polymorphisms' analyses}

When patients with AIH and OS were put together and compared to controls, it was found that HLA-DRB $1 * 13$ polymorphisms were approximately 7 -times more frequent in patients group than in controls $(\mathrm{OR}=7.2$, CI 2.83 to 19.94; $P<0.001)$. Regarding HLADRB1* 03 polymorphism, the frequency in the entire group of patients (AIH plus OS) was 3.5-fold higher ( $\mathrm{OR}=3.57$, CI 1.31 to 9.73; $P<0.01)$ if compared to controls. For the HLA-DRB $1 * 07$ and HLA-DRB $1 * 04$ polymorphisms, there was no statistical difference $(\mathrm{OR}=0.21, P=0.057)$ between patients and controls (TABLE 5).
TABLE 5. Logistic regression of polymorphisms HLA-DRB1.

\begin{tabular}{lccc}
\hline SNP & B $($ SE $)$ & OR $(95 \%$ CI $)$ & $P$ \\
\hline DRB1*03 & $1.27(0.51)$ & $3.57(1.31-9.73)$ & 0.013 \\
DRB1*07 & $-1.56(0.82)$ & $0.21(0.04-1.04)$ & 0.057 \\
DRB1*13 & $2.02(0.50)$ & $7.52(2.83-19.94)$ & 0.0001 \\
\hline
\end{tabular}

SNP: single nucleotide polymorphism. R2=0.95 (Hosmer and Lemeshow), 0.28 (Cox and Snell), 0.37 (Nagelkerke), X2 (3) of Model $=32.33$, DRB $1 * 04-$ variable removed in step 3 of 5. B: beta value; SE: standard error; OR: odds ratio; CI: confidence interval.

We also compared the frequency of polymorphisms between the groups of patients presenting $\mathrm{AIH}$ and $\mathrm{AIH}$ associated with autoimmune cholangitis. In this analysis, only HLA-DRB $1 * 13$ presented a significantly increased chance of about 4-fold of increase in the autoimmune cholangitis $(\mathrm{OR}=3.96, P=0.04)$ (TABLE 6).

TABLE 6. Logistic regression from polymorphisms HLA-DRB1 on groups AIH and overlap syndrome.

\begin{tabular}{lccc}
\hline SNP & B (SE) & OR (95\% CI) & $P$ \\
\hline DRB1*13 & $1.38(0.67)$ & $3.96(1.07-14.61)$ & 0.04 \\
\hline
\end{tabular}

SNP: single nucleotide polymorphism. R2=0.09 (Cox and Snell), 0.13 (Nagelkerke), X2 (1) of the Model $=4.481, \mathrm{DRB} 1 * 03-$ variable removed in step 5 of $7, \mathrm{DRB} 1 * 04-$ variable removed in step 4 of 7, DRB $1 * 07$ - variable removed in step 2 of 7 . B: beta value; SE: standard error; OR: odds ratio; $\mathrm{CI}$ : confidence interval.

\section{DISCUSSION}

Our results demonstrate the $H L A-D B R I^{*} 13$ and $H L A$ $D B R I * 03$ alleles were more frequent in the case than in comparison group. These results are in agreement with other studies ${ }^{(18,24,25)}$, since $H L A-D B R I^{*} 13$ polymorphism was more frequent in youngers. In the Fainboim 2001 study, the $H L A-D B R I * 13$ polymorphism predisposes to a persistent hepatitis A virus infection ${ }^{(26)}$. Czaja et al. 2002 incorporated the HLA-DBR $1 * 13$ alleles into the hypotheses of disease pathogenesis ${ }^{(18)}$. One of the main proposed mechanisms for the susceptibility determined by the HLA molecule to autoimmune diseases is the selective attachment of peptides to $\mathrm{MHC}$ molecules associated with diseases. Based on this, some groups have investigated common amino acids following the HLA molecules translated by the major alleles involved in AIH susceptibility. Analysis of the amino acid sequence transcribed by the three alleles present in caucasian AIH patients, which are HLA-DBR $1 * 03$, HLA-DBR $1 * 01$, and HLA-DBR $1 * 04$, have an increased frequency of lysine at position 71 of the third region of the DR $\beta$ chain ${ }^{(8,24)}$. This functional change could explain the susceptibility to disease in patients presenting with the HLA-DBR $1 * 0301$ polymorphism. As HLA DRB $1 * 13$ was associated with the highest relative chance for the disease, it is possible that a lysine at position 71 is not implicated in susceptibility to AIH-1 in the studied population ${ }^{(24)}$. On the other hand, the DRB1*13 and DRB1*03 alleles display high sequence homology to other relevant peptide binding sites. In fact, the gene encoding the DRB $1 * 03$ specificity evolved from DRB $1 * 13$ by gene conversion in the HLA-DRB1*13 / DRB3 haplotype. Thus, as both molecules are present in $91 \%$ of Brazilian AIH-1 patients, other common amino acid residues in the HLA-1 molecule site are shared $^{(24)}$ in some groups of South American children ${ }^{(25)}$. In Caucasians, the association also presented similar intriguing findings with the same HLA genes with autoimmune cholangitis in adulthood onset ${ }^{(27,28)}$. 
The HLA-DRB $1 * 07$ and HLA-DRB $1 * 04$ polymorphisms did not demonstrate statistical significance for association with AIH. Other studies have shown the HLA-DRB $1 * 07$ polymorphism acting as a protector against the disease, because it has a reduced frequency in the studied patients ${ }^{(13)}$. However, the HLA-DBR $1 * 04$ polymorphism in previous research in European Caucasian population showed a 4 to 5 -fold higher chance to present $\mathrm{AIH}(\mathrm{RR}=3.9$ and 4.97 ${ }^{(15,16)}$. In this study, the HLA-DRB1*04 and HLA- DRB1*07 does not show any statistical significance.

Other research in the Brazilian population did not find an association of HLA-DRB $1 * 04$ polymorphism in patients with $\mathrm{AIH}^{(24)}$. Asian populations, like the Japanese, seems to have a higher frequency of all HLA-DRB $1 * 04$ alleles in adult-onset with AIH-1. The HLA-DRB $1 * 0405$ allele was also investigated in adults with AIH-1 in Argentina and with the acute disease in Mexico ${ }^{(18,29,30)}$. There was no change in the frequency of HLA-DRB1*04 in the population studied, or any Brazilian population ${ }^{(24)}$.

The patient's group was subdivided into groups according to the way the disease presented clinically to investigate predictive factors of the clinical presentation. Then, these patients were evaluated about polymorphisms to investigate if they would be able to predict the presence or absence of cirrhosis in patients with $\mathrm{AIH}$ or AIH associated with overlap syndrome. None predictive factor was statistically significant for the groups of patients studied $(P>0.05)$. When comparing the polymorphisms between the AIH and autoimmune cholangitis groups, the only one able to predict a 3-fold increased chance of the presence of an overlap syndrome was the polymorphism $H L A-D R B 1 * 13(\mathrm{OR}=3.96, P<0.05)$.

This study is a case series composed of 43 patients, subdivided into $\mathrm{AIH}$ and $\mathrm{AIH}$ associated with overlap syndrome. This disease is a very rare disease, so the sample size is a real limitation for any assumption. In regression, the determination of sample size will depend on the extent of the effect being attempted and how much power is needed for this effect. As a general rule, it is possible to have 10 or 15 data for each model predictor ${ }^{(28)}$. For the first experiments, which included patients and controls, our sample size was 100 individuals for two predictors; these predictors were the presence or absence of the disease. These analyses were statistically significant. Secondary, the sample size was reduced to 43 , to investigate whether the polymorphisms would predict AIH cirrhosis and evolution to autoimmune cholangitis. It was possible to observe statistical significance. However, in the last analysis to have an ability to predict outcomes having a reduced sample size $(n=43)$, using four variables
(DRB1*04,DRB1*07, DRB1*03 and $D R B 1^{*} 13$ ) we have sample constraints. In view of the presented, larger sample is necessary to evaluate the ability of these polymorphisms to predict the degree of aggravation of the disease and the presence or absence of cirrhosis in the population with the evaluated characteristics.

\section{CONCLUSION}

$\mathrm{AIH}$ and its association with cholangitis autoimmune are a challenging condition for the patient and the scientific community. As a rare disease, the main limitation of this study was the reduced number of patients evaluated with $\mathrm{AIH}$ and this condition associated with cholangitis.

However, this work contributed to the investigation of the main polymorphisms in the $H L A-D R B 1$ gene associated with $\mathrm{AIH}$ with or without cholangitis in young population. It has been shown that children with $H L A-D R B I * 03$ and $H L A-D R B 1 * 13$ polymorphisms are more likely to be affected with AIH, and children with $H L A$ $D R B 1^{*} 13$ polymorphism are still likely to develop the association with autoimmune cholangitis.

\section{ACKNOWLEDGEMENTS}

Grants from FAPEMIG, CNPq and CAPES who support the research in Brazil.

\section{Authors'contribution}

Nunes MEG: acquisition, analysis and interpretation of data; statistics analysis; manuscript preparation. Rosa DV: scientific, conception and design of the study; manuscript preparation. Fagundes EDT, Ferreira AR: conception and design of the study, sample collection, paper revision. Miranda DM: scientific, intellectual, conception and design of the study; manuscript preparation, critical revision. Ferri Liu PM: scientific, intellectual, conception and design of the study; critical revision.

\section{Orcid}

Monique Ellen Gervásio Nunes. Orcid: 0000-0002-4291-9221. Daniela Valadão Rosa. Orcid: 0000-0001-8868-7895.

Eleonora Duvre Tavares Fagundes. Orcid: 0000-0002-5671-9570. Alexandre Rodrigues Ferreira. Orcid: 0000-0001-6749-8980.

Débora Marques de Miranda. Orcid: 0000-0002-7081-8401.

Priscila Menezes Ferri Liu. Orcid: 0000-0002-8608-8503.

Nunes MEG, Rosa DV, Fagundes EDT, Ferreira AR, Miranda DM, Ferri Liu PM. Polimorfismos do gene HLA-DRBI em pacientes pediátricos com hepatite autoimune tipo 1 e hepatite autoimune associada à colangite autoimune. Arq Gastroenterol. 2019;56(2):146-50.

RESUMO - Contexto - Hepatite autoimune (HAI) é uma doença hepática inflamatória crônica, rara, associada à perda da tolerância imunológica aos auto-antígenos. A susceptibilidade à HAI é parcialmente determinada pela presença de genes relacionados ao antígeno leucocitário humano (HLA), principalmente variantes alélicas do $D R B 1$. Objetivo - O objetivo deste estudo foi investigar a frequência de polimorfismos no gene $H L A-D R B 1$ em crianças e adolescentes com HAI tipo 1 e HAI tipo 1 associada à colangite autoimune, em comparação com indivíduos saudáveis pareados por sexo e idade (grupo controle). Métodos - Este é um estudo transversal de 25 pacientes pediátricos com diagnóstico de HAI tipo $1 \mathrm{e} 18$ com HAI associada à colangite autoimune. Cinquenta e sete indivíduos saudáveis foram incluídos como controles. Os polimorfismos do gene $H L A$ - $D R B 1$ foram avaliados por PCR e incluíram $H L A-D R B 1 * 03, H L A-D R B 1 * 04, H L A-D R B 1 * 07$ e $H L A-D R B 1 * 13$. Resultados - Nossos resultados mostraram que a presença do alelo $H L A-D R B 1^{*} 13$ aumentou a chance de colangite autoimune $(\mathrm{OR}=3,96$; IC 1,07 a 14,61; $P=0,04)$. O HLA-DRB1*04 e o $H L A-D R B 1^{*} 07$ não apresentam associação com a HAI e colangite autoimune no grupo de pacientes mais jovens. Conclusão - Este trabalho demonstra uma associação dos principais polimorfismos no gene $H L A-D R B 1$ à HAI com ou sem colangite na população brasileira.

DESCRITORES - Hepatite autoimune. Colangite esclerosante. Cadeias HLA-DRB1. Polimorfismo genético. 


\section{REFERENCES}

1. Manns MP, Czaja AJ, Gorham JD, Krawitt EL, Mieli-Vergani G, Vergani D, et al. Diagnosis and management of autoimmune hepatitis. Hepatology. 2010;51: 2193-213

2. Longhi MS, Mieli-Vergani G, Vergani D. Autoimmune hepatitis. Curr Pediat Rev. 2014;10:268-74.

3. Mieli-Vergani G, Vergani D. Autoimmune hepatitis in children: what is different from adult AIH? Semin Liver Dis. 2009;29:297-306.

4. Gregorio G V, Portmann B, Karani J, Harrison P, Donaldson PT, Vergani D, et al. Autoimmune hepatitis/sclerosing cholangitis overlap syndrome in childhood: a 16-year prospective study. Hepatology. 2001;33:544-53.

5. Ferri Liu PM, de Miranda DM, Fagundes EDT, Ferreira AR, Simões e Silva AC. Autoimmune hepatitis in childhood: the role of genetic and immune factors World J Gastroenterol. 2013;19:4455-63.

6. Czaja AJ, Carpenter HA, Moore SB. HLA DRB1*13 as a risk factor for type autoimmune hepatitis in North American patients. Dig Dis Sci. 2008;53:522-8.

7. de Boer YS, van Gerven NMF, Zwiers A, Verwer BJ, van Hoek B, van Erpecum $\mathrm{KJ}$, et al. Genome-wide association study identifies variants associated with autoimmune hepatitis type 1. Gastroenterology. 2014;147:443-52.e5.

8. Donaldson PT. Genetics in autoimmune hepatitis. Semin Liver Dis. 2002;22 353-64.

9. Donaldson PT. Genetics of liver disease: immunogenetics and disease pathogenesis. Gut. 2004;53:599-608

10. Oo YH, Hubscher SG, Adams DH. Autoimmune hepatitis: new paradigms in the pathogenesis, diagnosis, and management. Hepatol Int. 2010;4:475-93.

11. Tang J, Zhou C, Zhang Z-J, Zheng S-S. Association of polymorphisms in non-classic MHC genes with susceptibility to autoimmune hepatitis. Hepatobiliary Pancreat Dis Int. 2012;11:125-31

12. Heneghan MA, Yeoman AD, Verma S, Smith AD, Longhi MS. Autoimmune hepatitis. Lancet. 2013;382:1433-44.

13. Donaldson PT, Doherty DG, Hayllar KM, McFarlane IG, Johnson PJ, Williams R. Susceptibility to autoimmune chronic active hepatitis: human leukocyte antigen DR4 and A1-B8-DR3 are independent risk factors. Hepatology. 1991;13:701-6.

14. Strettell MD, Donaldson PT, Thomson LJ, Santrach PJ, Moore SB, Czaja AJ, et al. Allelic basis for HLA-encoded susceptibility to type 1 autoimmune hepatitis. Gastroenterology. 1997;112:2028-35.

15. Doherty DG, Donaldson PT, Underhill JA, Farrant JM, Duthie A, Mieli-Vergan $\mathrm{G}$, et al. Allelic sequence variation in the HLA class II genes and proteins in patients with autoimmune hepatitis. Hepatology. 1994;19:609-15.

16. Montano-Loza AJ, Carpenter HA, Czaja AJ. Clinical significance of HLA DRB103-DRB104 in type 1 autoimmune hepatitis. Liver Int. 2006;26:1201-8.
17. Czaja AJ, Souto EO, Bittencourt PL, Cancado ELR, Porta G, Goldberg AC, et al. Clinical distinctions and pathogenic implications of type 1 autoimmune hepatitis in Brazil and the United States. J Hepatol. 2002;37:302-8.

18. Czaja AJ, Manns MP. Advances in the diagnosis, pathogenesis, and management of autoimmune hepatitis. Gastroenterology. 2010;139:58-72.e4

19. Alvarez F, Berg PA, Bianchi FB, Bianchi L, Burroughs AK, Cancado EL, et al. International Autoimmune Hepatitis Group Report: review of criteria for diagnosis of autoimmune hepatitis. J Hepatol. 1999;31:929-38.

20. Hennes EM, Zeniya M, Czaja AJ, Parés A, Dalekos GN, Krawitt EL, et al Simplified criteria for the diagnosis of autoimmune hepatitis. Hepatology. 2008:48:169-76.

21. Lahiri DK, Schnabel B. DNA isolation by a rapid method from human blood samples: effects of $\mathrm{MgCl} 2$, EDTA, storage time, and temperature on DNA yield and quality. Biochem Genet. 1993:31:321-8.

22. Zetterquist H, Olerup O. Identification of the HLA-DRB1*04, -DRB1*07, and -DRB1*09 alleles by PCR amplification with sequence-specific primers (PCRSSP) in 2 hours. Hum Immunol. 1992;34:64-74.

23. Diao B, Du J, Liu Y, Luo F, Hou W. The association of HLA-DRB1 alleles and drug use with HIV infection in a Chinese Han Cohort. Braz J Infect Dis. 2014:18:82-7.

24. Bittencourt PL, Goldberg AC, Cançado EL, Porta G, Carrilho FJ, Farias AQ, e al. Genetic heterogeneity in susceptibility to autoimmune hepatitis types 1 and 2. Am J Gastroenterol. 1999;94:1906-13.

25. Pando M, Larriba J, Fernandez GC, Fainboim H, Ciocca M, Ramonet M, et al Pediatric and adult forms of type I autoimmune hepatitis in Argentina: evidence for differential genetic predisposition. Hepatology. 1999;30:1374-80.

26. Fainboim L, Cañero Velasco MC, Marcos CY, Ciocca M, Roy A, Theiler G, et al. Protracted, but not acute, hepatitis A virus infection is strongly associated with HLA-DRB*1301, a marker for pediatric autoimmune hepatitis. Hepatology. 2001;33:1512-7.

27. Gregorio G V, Portmann B, Reid F, Donaldson PT, Doherty DG, McCartney M, et al. Autoimmune hepatitis in childhood: a 20-year experience. Hepatology. 1997;25:541-7

28. Mieli-Vergani G, Vergani D. Sclerosing cholangitis in the paediatric patient. Best Pract Res Clin Gastroenterol. 2001;15:681-90.

29. Doherty DG, Donaldson PT. HLA-DRB and DQB typing by a combination of serology, restriction fragment length polymorphism analysis and oligonucleotide probing. Eur J Immunogenet. 1991;18:111-24

30. Doherty DG, Vaughan RW, Donaldson PT, Mowat AP. HLA DQA, DQB, and DRB genotyping by oligonucleotide analysis: distribution of alleles and haplotypes in British caucasoids. Hum Immunol. 1992;34:53-63. 